\title{
English Language Children's Literature as a Springboard for Teacher-Researcher International Collaboration
}

\author{
Trentinné Benkő, Éva ${ }^{l}$, Árva, Valéria ${ }^{1}$, \\ Medina-Casanovas, Núria ${ }^{2} \&$ Canals-Botines, Mireia ${ }^{2}$ \\ ${ }^{1}$ Department of Foreign Languages and Literature \\ Faculty of Primary and Preschool Education, ELTE \\ ${ }^{2}$ Department of Philology, Literature and Language Teaching. Faculty of Education, Translation \\ and Humanities, Universitat de Vic-Universitat Central de Catalunya
}

\begin{abstract}
This article discusses various forms of collaboration in terms of research, teaching and innovation conducted in the field of children's literature by four lecturers from the University of Vic-Central University of Catalonia (Uvic-UCC), Catalonia (Spain) and Faculty of Primary and Preschool Education, Eötvös Loránd University (ELTE TÓK), Budapest (Hungary). The research project that focused on the use of stories, songs and rhymes in the early English language education provided at a number of primary and preschools in Catalonia and Hungary forms the centrepiece of this joint study. The present article is an account of the follow-up research that completed the project.
\end{abstract}

Keywords: children's literature; stories, songs and rhymes; international collaboration; TEYL (teaching English to young learners); teachers as researchers

\section{Introduction}

The present article analyses the follow-up study of a joint research project conducted by university lecturers in Catalonia and Hungary and gives an account of how Erasmus + staff mobility can form the starting point for a larger scale of international collaboration among university educators. Mutual visits taken as a part of the Erasmus+ staff mobility enabled the authors to realise that they held a common field of interest: English children's literature in young learners' holistic development and foreign language teacher education. Each of the four authors had been teaching and researching this field, a factor that initially led to establishing contact. This successful cooperation further evolved into projects consisting of joint research, offand online guest teaching, and a strategic Erasmus+ partnership. 
As part of their primary and preschool teacher training, both the University of Vic and ELTE TÓK offer specialisations in English language teaching. The University of Vic operates a BA programme in Early Childhood Education with an English specialisation. ELTE TÓK runs a specialisation in Hungarian-English bilingual preschool education (BA level, three years) and teaching English as a foreign language in primary education (BA level, four years). Other than these programmes, ELTE TÓK primary teacher trainees can opt for an extra CLIL (Content and Language Integrated Learning) module that prepares them for teaching in bilingual schools. There is also a specialised, in-service training programme for practising primary teachers who want to qualify to become English language teachers in grades 1-6 (i.e. for pupils aged 6-12).

Our study refers to the authors as university lecturers or researchers and to primary school teachers and kindergarten educators as teachers. The terms kindergarten and preschool are both used to refer to educational institutions for children aged 3-5/6. University students will be called students, teacher trainees or student teachers.

\section{The history of international cooperation between Vic and Budapest}

This section contains a summary and a timeline of the cooperation among the four lecturers and their institutes starting in 2016. Teachers from the primary and preschool sectors joined the university research team in 2018. This fruitful collaboration paved the way for ELTE TÓK to participate in a European project led by the University of Vic, as a member of an international team from four countries in 2020.

After the Hungarian part of the team participated in an Erasmus+ mobility visit to Catalonia in 2016, a request for a joint research project was sent from Vic to Budapest in 2018. As was mentioned previously, the common field of interest was children's literature in TEYL (Teaching English to Young Learners). A year of data collection conducted at schools in Catalonia had preceded this joint research project. An Erasmus+ staff mobility visit enabled the Catalan researchers to launch the project in Budapest. Before the colleagues arrived from Vic, practising teachers of young learners were selected and contacted by the Hungarian researchers. During their stay, the Catalan researchers became acquainted with the Hungarian education system, the role of foreign language teaching and learning in it, and the relevant teacher training specialisations at ELTE TÓK. They also paid visits to the chosen schools and preschools to observe TEYL in practice, conduct interviews with the participant teachers, and hand over the data collection sheets they had developed. The researchers asked the teachers to note and reflect upon their use of songs and rhymes in their teaching. Having finished the school visits, one of the Catalan colleagues stayed in Hungary for the term to monitor the research and teach a Children's Literature course at ELTE TÓK as a guest lecturer. 
The next phase consisted of the authors' participation in the international conference, Storytelling Revisited: Gender, Language, Music Cinema (2018), held in Vic. Each project participant gave a keynote speech at the conference. The Catalan researchers' lecture reflected upon their children's literature project findings in Vic schools (Canals-Botinas \& Medina-Casanovas, 2019), while the Hungarian guest speakers elaborated upon the theme of stories and storytelling from perspectives relevant to their research interests (Árva, 2019; Trentinné Benkő, 2019).

During the academic year of 2018/19, the teachers collected data in the Hungarian schools that the researchers at ELTE TÓK processed. The colleagues in Vic analysed the data, then compared them to the results gathered in Catalonia. They presented the final results at the second Storytelling Revisited conference in Vic in 2019 (Canals-Botinas \& Medina-Casanovas, 2020). Meanwhile, the Catalan researchers from the University of Vic initiated an Erasmus+ K2 project and invited their Hungarian partners to participate. Although the project called 'WIN' (Writing for Inclusion) did not win in 2019, the second submission succeeded in 2020. Before this, each participating university partner carried out a survey connected to the topic of the planned project that targeted university lecturers, teachers, and student teachers in their home countries. WIN is a project that combines the fields of children's literature and the pedagogy of inclusion. The University of Vic is the host of the project, joined by the University of Florence (Italy), ELTE TÓK (Hungary) and the University of Poltava (Ukraine). The project involves exploring and developing a digital storytelling application that can be utilised in schools to promote the concepts of inclusion and cultural integration.

The participating colleagues consist of two university lecturers from each partner university and a primary school teacher from each country. ELTE TÓK is responsible for developing the relevant methodology and organising the training programme for teachers who would like to use the application. Led by the University of Vic, the project has made progress despite the challenges posed by the current pandemic situation worldwide since tasks have been managed online.

After having established a deep and meaningful professional relationship and becoming familiar with each other's teacher training programmes, the authors developed the option of conducting another, albeit informal, form of cooperation that would create space and opportunities for each other as guest lecturers in their respective online Children's Literature courses. This project serves several institutional and individual purposes, each of which is equally important. First and foremost, both partner institutions can enhance their on-campus internationalisation at a time when physical travel is not possible. Online co-teaching is also invaluable from the individuals' point of view. Inviting guest lecturers and bringing in an international professional perspective can be an invigorating experience for students and lecturers alike. Figure 1 summarises the stages in professional cooperation that the University of Vic and ELTE TÓK have nurtured. 


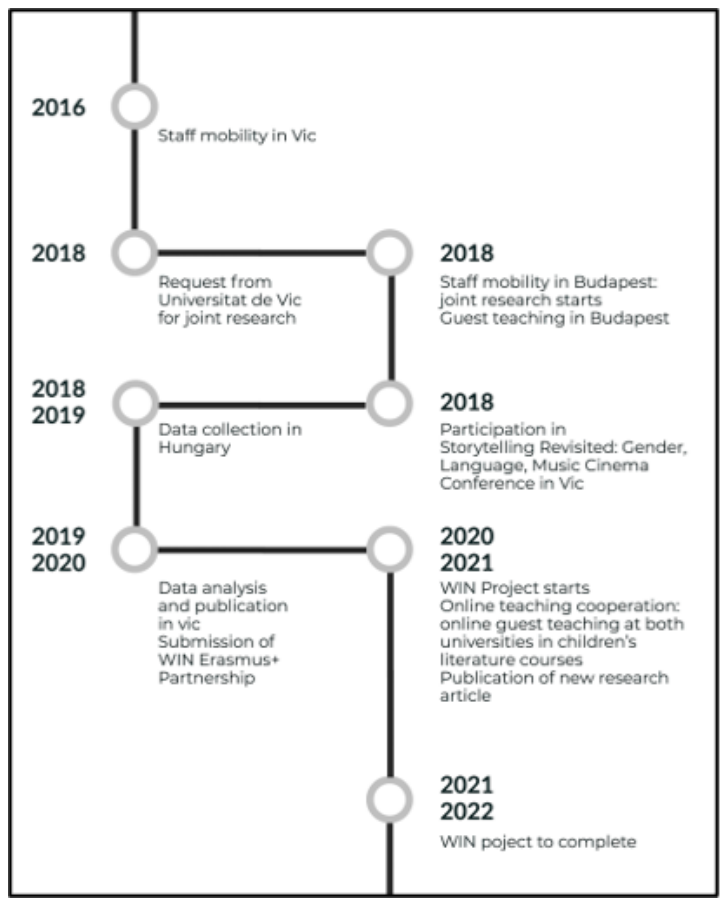

Figure 1

Timeline for the growth of professional cooperation

\section{Theoretical background and the joint research project}

This article aims to supplement the original research project "Songs and narrative structures in storybooks for young learners". Canals-Botines and Medina-Casanovas $(2019,2020)$ launched this research to investigate the narrative structures of the stories and songs used in preschool and primary English language teaching. They were interested in researching songs because singing has a motivating and joyful effect on children. According to Coyle \& Gómez Gracia (2014) and Fonseca-Mora (2000), songs are unambiguously beneficial in the process of language acquisition and language learning.

The Catalan researchers regarded stories as another essential form of language learning for young learners. Stories can play a central role in young children's language acquisition process in both their native and foreign language development. Bland (2016) distinguishes between oral storytelling and picture books while emphasising the latter's role in the case of children who cannot yet read. As Mourao (2016) argues, picture books 
are instrumental in the gradual development of children's reading skills both in native and foreign language development. Reading picture books can be regarded as the young learners' equivalent of watching films, since they are both 'visual reception activities' (Council of Europe, 2020). Picture books allow children to read the text and use the pictures as support for meaning making.

The presence of English Children's Literature Studies in teacher training programmes is in accord with the current recognition of literature's place in children's language learning process (Bland, 2019; Ellis \& Brewster, 2012). Children's literature represents authentic and meaningful language input, ensures exposure to motivating language, engages children's interest, and promotes learning complex, often repetitive, multi-item chunks instead of single words in isolation (Bland, 2019; Kersten, 2016). Children's literature is also a means for transmitting information regarding children's culture in English-speaking countries. Finally, children's literature can provide emotional support to young and very young learners of English.

Table 1 summarises the topics that English children's literature courses include at ELTE TÓK (ELTE TÓK, 2020). The Department of Foreign Languages and Literature offers two terms of children's literature studies to preschool trainees and three to future primary teachers. The third course focuses on youth or juvenile literature, which is not essential for working with preschoolers. The children's literature classes complement the methodology courses in the syllabus. The students familiarise themselves with the literary texts, theorise about their application to language teaching and apply their knowledge of methodology while experimenting with using these texts.

Table 1

English Children's Literature Courses at ELTE TÓK

\begin{tabular}{|l|l|c|c|c|}
\hline \multicolumn{1}{|c|}{ Course } & \multicolumn{1}{|c|}{ Topic } & Age group & $\begin{array}{c}\text { Preschool } \\
\text { programme }\end{array}$ & $\begin{array}{c}\text { Primary pro- } \\
\text { gramme }\end{array}$ \\
\hline $\begin{array}{l}\text { English } \\
\begin{array}{l}\text { Children's } \\
\text { Literature 1 }\end{array}\end{array}$ & $\begin{array}{l}\text { Short genres } \\
\text { (nursery rhymes, } \\
\text { children's poems, } \\
\text { songs, games, ridd- } \\
\text { les, etc.) }\end{array}$ & $\begin{array}{l}3-6, \\
6-12\end{array}$ & $\checkmark$ & $\checkmark$ \\
\hline $\begin{array}{l}\text { English } \\
\text { Children's } \\
\text { Literature 2 }\end{array}$ & $\begin{array}{l}\text { Stories (fairy tales, } \\
\text { picture books) }\end{array}$ & $3-6$, & $\checkmark$ & $\checkmark$ \\
\hline $\begin{array}{l}\text { English } \\
\text { Children's } \\
\text { Literature 3 }\end{array}$ & Juvenile literature & $6-12$ & $\times$ & $\checkmark$ \\
\hline
\end{tabular}


The expected learning outcomes for these courses include the following: the ability to appreciate the role of children's literature in young learners' holistic development, awareness of the main genres, knowledge of a certain number of traditional, classic and contemporary pieces of children's literature, and the ability to utilise these works in practice. In other words, trainees learn about children's literature and acquire a familiarity with numerous literary pieces. Beyond this knowledge, they also master the professional skills, attitudes, and autonomy needed to integrate this experience into their practice by applying age-appropriate teaching methodologies. The lecturers aim to achieve this learning outcome through experiential learning activities held at the seminars and involving creative projects, read-aloud, and microteaching sessions (Trentinné Benkő, 2016).

The Early Childhood Education BA programme in Vic also places a strong emphasis on children's literature. The programme has an English specialisation that contains an English Children's Literature course. In addition to this subject, the methodology course syllabi also contain many children's literature-related topics.

\section{Research framework and procedure}

This research project took place between 2018 and 2020 and involved data collection through interviews and filling in forms (see data collection chart in Appendix A). The researchers asked participating preschool and primary school teachers to keep a log of the songs and stories they used throughout an entire school year. Teachers had to submit the data collected three times a year: at Christmas, Easter, and at the end of the school year.

Canals-Botines \& Medina-Casanovas' (2019) research sought to answer the following questions:

1. What narrative structures are used for preschool and primary education in EFL teaching?

2. What is the relevance of pupils' gender construction roles in the narrative structures used in EFL teaching?

3. How can we classify the songs used in EFL teaching for preschool and primary education?

4. How do songs and stories help in the competency-based curriculum? (pp. 30-31)

Data collection was first carried out in Catalonia followed by another one conducted a year later in Budapest. The process took two school years. The research results from Catalan schools were published first (Canals-Botines \& Medina-Casanovas, 2019), followed by an analysis of Hungary's data and its publication (Canals-Botines \& Medina-Casanovas, 2020). The classification system used to categorise the songs and stories was based upon the Catalan data analysis. The classification categories reflect the Children's Literature course topics at the University of Vic. The types of songs, the narrative 
structures of the stories, and finally, the distribution of them between school types, grades and terms were carefully examined and analysed. (Figure 2)

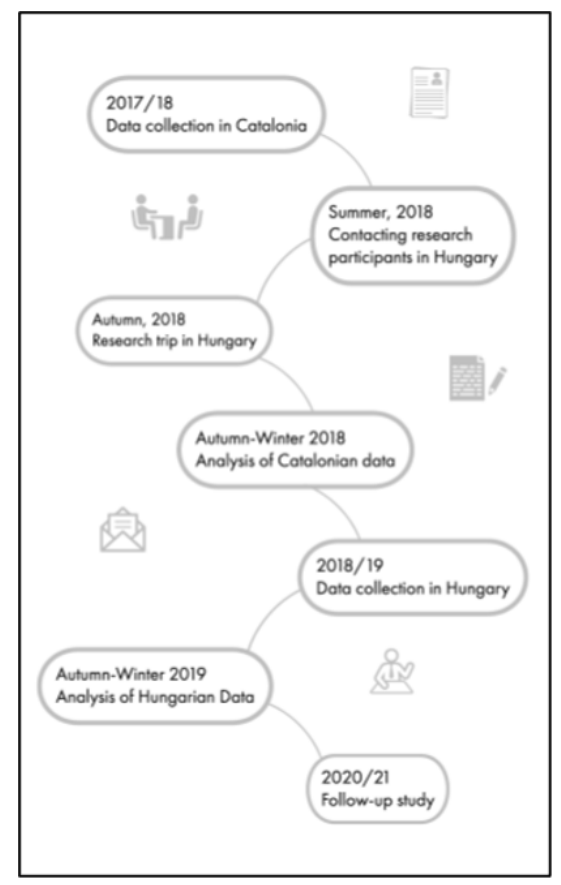

Figure 2

Time frame of the research

In their first study, Canals-Botines \& Medina-Casanovas (2019) identified and compiled a classification system for the songs and the stories collected (Table 2). Their analysis involved the systematic categorisation and the distribution of songs and stories between the schools, genres and types, and years and terms. They identified tailor-made stories as the most popular narrative structures (Canals-Botines, 2020). 
Table 2

Classification of songs and narrative structures (Canals-Botines E Medina-Casanovas, 2019, pp. 29-30)

\begin{tabular}{|l|l|}
\hline \multicolumn{1}{|c|}{ Types of songs } & \multicolumn{1}{c|}{ Narrative structures } \\
\hline Mother Goose nursery rhymes & Basic causal structure \\
Children's songs & Dramatic positive response in a causal \\
Tailor-made songs & structure \\
Songs after popular melodies & Dramatic negative response in a causal \\
Modern/Present day songs & structure \\
Songs for stories & Descriptive structure \\
& Serpent structure \\
& Repetition structure \\
\hline
\end{tabular}

In Hungary, three preschools (ages three to five or six) and three primary schools (ages six to twelve) participated in this research project. The three kindergartens all run a bilingual programme, are operated privately, and one follows the Montessori method. Both situated in Budapest, two of the primary schools are public institutions. The third school, however, is a private school located in a small town near Budapest. Although according to the Hungarian National Core Curriculum (2020), compulsory foreign language instruction only starts in the fourth grade, the participating primary schools introduce English beginning in the first year. This early start was a necessary element in the schools' selection due to the need to identify institutions offering foreign language education at a level similar to that found in the schools studied in Catalonia. Two of the Hungarian schools offer a CLIL programme, which means that English is the language of instruction in some subjects in addition to being taught as a foreign language from the first grade. At each institution, one teacher had been contacted and asked to keep a log of the stories and songs used during the 2018-19 school year.

The results of the data analysis presented at the Storytelling Revisited 2019 Conference and subsequently published (Canals-Botines \& MedinaCasanovas, 2020) showed that, in general, many songs were in use at all participating Hungarian schools. However, singing peaked during Early Years and Grade 1. In reference to the application of stories, the data revealed that the three most frequently used narrative structures were Basic-Causal, Descriptive and Repetition structures (pp. 57-58).

\section{Follow-up research: Stories}

In the discussion below, only the data gained from four Hungarian schools will be examined since our information regarding the remaining schools was insufficient. In one instance, the whole year's log-keeping may have proved 
exhausting as the participating teachers stopped sending data after the first term. Another participant almost exclusively used stories from her pupils' English coursebook; thus, the log did not provide sufficient data concerning her choice of stories as supplementary materials.

The data attained from the four teachers' composite list of picture books used in the four schools and preschools proved impressive. Out of the four schools, altogether 124 titles were collected and used. What makes this list interesting is that it contains a wide variety of stories used in language teaching and development. The sheer number seems to suggest the extent to which teachers of young learners rely upon stories in their teaching.

After a careful examination of the list, the following observations can be made. The total number of books is almost evenly distributed among the schools and kindergartens, implying that picture books can be equally used among both preschool and lower primary learners. The high number of books suggests that teachers rely upon picture books to a great extent and are comfortable using them for teaching purposes. It can be safely assumed that the teachers accumulated a great deal of pedagogical expertise and many teaching tools in order to transform picture books into effective language teaching materials.

The high number (119) of different stories used by the participating teachers was somewhat unexpected and can be attributed to several factors. Each teacher might have a selection of favourite stories that are preferred. It is also likely that teachers depend upon the widely different collections found in the school library, or even receive children's books from parents or friends. It should also be considered that the participating teachers are non-native teachers; English language children's literature is not something they grew up with as children. They are likely to have learned about the stories and picture books in their adult life, either as students or as practising English teachers. Therefore, the teachers' exposure to children's literature is less determined by traditional cultural choices than by other factors. Such determinants can be the books' appeal to them as adults, their university lecturers' preferences, their colleagues' taste, or mere coincidences, such as availability in local bookshops.

The availability of Hungarian translations may also influence teachers in their choice of books. They may be consciously choosing titles that are available in Hungarian because the children might have been previously exposed to them. An examination of the complete list revealed that twentyfive of the picture books are available in Hungarian. They include classic fairy tales, such as Goldilocks, The Three Little Pigs or Snow White, classic English children's books by Milne or Dr Seuss and several recent popular publications. The Gruffalo and The Very Hungry Caterpillar, two everpopular picture books, are also available in Hungarian. A growing body of books by Julia Donaldson and Axel Scheffler, whose stories seem to be gaining in popularity in Hungary, has also been translated into Hungarian. 
The popularity of Thomas the Tank Engine may stem from the fact that, for the past two decades, young children have watched the animated film series in Hungary. When reading these books in the English classroom or preschool sessions, many children see stories and pictures that they already know from earlier home experience, a circumstance that may help them both emotionally and linguistically. As was mentioned previously, each teacher's list is almost entirely different from the others; few stories were used by more than one teacher.

Only six out of the 124 books were listed by more than one participant: The Very Hungry Caterpillar (by Eric Carle), The Gruffalo (by Julia Donaldson and Axel Scheffler), We're Going on a Bear Hunt (by Michael Rosen and Helen Oxenbury), Goldilocks and the Three Bears, Winnie the Witch and Winnie and Wilbur Meet Santa (by Valerie Thomas and Paul Corky). The first three titles can be found on several lists of 'most popular children's books' (Time, Time Out, New York Public Library) and can be regarded as classics among children's books. Goldilocks is a famous fairy tale in the English-speaking world. The two books featuring Winnie the Witch were published by Oxford University Press, a leading ELT (English Language Teaching) publishing house, and target the English teaching market. Their popularity is further enhanced by the numerous supplementary materials and frequent teacher training events organised by the publishing house. Although the Winnie stories are recommended for young language learners, they are not graded readers that feature simplified language. Quite the contrary, they contain authentic language and, due to their well-developed characters and lively storylines, can be enjoyed immensely by learners and teachers alike.

Mentioned six times on the list, the most frequently used book is Eric Carle's The Very Hungry Caterpillar. This result is hardly surprising, considering this story's overwhelming success among children in Englishspeaking countries and worldwide. Published more than fifty years ago in 1969, this work continues to appeal to generations of young children while additionally teaching them the life cycle of a butterfly, numbers, healthy eating and the days of the week. This book has been frequently featured on the 'best ever' children's books lists of magazines, such as Time Out (URL1), Time Magazine (URL2), or public libraries, such as the New York Public Library (URL3). The Very Hungry Caterpillar has been awarded numerous literary awards that are listed on the author's website (URL4).

To return to the results gathered by the University of Vic team, seven primary and preschool groups participated in the Catalan part of the research. According to the data provided, teachers used 59 stories and picture books throughout the school year. This number equals half of the stories utilised in the four Hungarian schools. Six of the stories are traditional fairy tales, such as The Gingerbread Man or Three Billy Goats, while the rest are picture books. Based on the data, fairy tales seem to be relatively more popular in Catalan than in Hungarian classrooms. The last two works on the 
most frequently used books list were Brown Bear, Brown Bear and The Very Hungry Caterpillar by Eric Carle. Teachers both in Hungary and Catalonia find Carle's books very appealing.

\section{Follow-up research: Songs and rhymes}

The songs and rhymes that the teachers used in one school year were also collected and listed by the researchers. The composite list of more than 200 songs and rhymes is indeed impressive: both the Catalan and Hungarian participant teachers appear to use a wide range of songs and rhymes in their language teaching.

First of all, some experiences from the data processing phase will be shared before continuing on to a brief analysis of the findings. In most cases, the children's literature elements were easy to identify based on their titles alone; however, there were some more challenging items. The following factors supported the researchers' task in this process. The list included many well-known and popular pieces that English teachers are usually familiar with because of their role in children's culture and language teaching. These are the following, to mention just a few: Happy Birthday Song, ABC Song, Are You Sleeping?, Incy-Wincy Spider, Twinkle Twinkle Little Star or Row, Row, Row Your Boat. The list includes traditional nursery rhymes such as Baa, Baa Black Sheep and This Old Man, or children's songs like Hockey Pockey, If You're Happy and You Know It or The Wheels on the Bus. Also, researchers were able to identify literary works when the teachers provided certain additional information, such as a YouTube link or the author's name (Anywhere by Rita Ora, Winnie's Song URL5, Penguin Song URL6, Owl Song URL7, Clean up Song URL8).

The challenging factors for identification included the following examples. Well-known songs may appear in different versions concerning the lyrics or the titles, so the researchers could only assume that they were the same pieces (One, Two, Three, Four; Ten Little Fingers, Who Took the Candy, Five Little Monkeys). At other times, it was either challenging or almost impossible to identify particular songs and rhymes since many of them have similar titles (Hello, Hello; Farm Animals, The Weather Song, Days of the Week, Fruit Song). The tailor-made songs and chants found in various coursebooks also proved challenging to identify since these songs were specifically created to suit a teaching unit's particular topic (Welcome to Park Street, What Colour Is Mum's Hat, The Frisbee Song). However, it was possible to identify some of them by checking the particular textbooks being used (e.g. In, On, Under Song). Primary and preschool teachers also regularly use materials learnt in their pre-service and in-service training courses and workshops. Furthermore, they tend to supplement their original repertoire with songs and rhymes gathered from the Internet, various resource books, or their local and visiting colleagues. 
What can be observed is the tendency for children's literature to be linked to all the themes that appear in the National Core Curriculum and primary or preschool local curriculum. The most common comprehensive topic for the youngest language learners in both primary and preschool contexts is greetings. Most EFL teachers of young learners know and tend to use children's literature for classroom management purposes. These songs and rhymes can help make better use of classroom time: transition times or classroom rituals, such as clean-up time, can be exploited for language development. Several songs and rhymes focus on body parts and provide opportunities for physical movement during the lesson. Animals are an eternal topic that appeals to children, and songs and rhymes about the family are also frequently used. Similarly, weather topics, such as pieces related to seasons and the theme of food and drinks, are also common among songs and rhymes. Since the study focuses on young learners aged three to ten, it is not surprising that the common themes include numbers and colours, too. Holidays and festivals have their special songs in each culture. Finally, songs and rhymes may supplement, or even tell stories themselves. The topics listed here may in some cases overlap; for example, The Rainbow Song suits the topics of both the weather and the colours (see Table 3).

Table 3

Songs and rhymes in the curriculum

\begin{tabular}{|l|l|}
\hline \multicolumn{1}{|c|}{$\begin{array}{c}\text { Topics in the } \\
\text { curriculum }\end{array}$} & \multicolumn{1}{c|}{ Songs and rhymes (Examples) } \\
\hline Greetings & $\begin{array}{l}\text { Hello, Girls and Boys, Hello Children, Hello Friends, Hi, How Are You, } \\
\text { Hello and How Are You, Hello and Goodbye, Way up in the Sky, Bye- } \\
\text { Bye Goodbye, Hello and Have a Nice Day }\end{array}$ \\
\hline $\begin{array}{l}\text { Classroom ma- } \\
\text { nagement }\end{array}$ & $\begin{array}{l}\text { Make a Circle Round, Round, Round; 1,2,3, Come to Me, Clean-up } \\
\text { Song, Hide and Seek, Today Is Monday, How Old Are You? Who Took } \\
\text { the Candy? Tommy Thumb Where Are You? }\end{array}$ \\
\hline Body parts & $\begin{array}{l}\text { Head and Shoulders, One Little Finger, Tommy Thumb, Bend Your Kne- } \\
\text { es, Arms Up, Babyface, Clap Your Hands, Stamp Your Feet, Eyes and } \\
\text { Mouth and Nose, From Head to Toe, Skeleton Dance, Hockey-Pockey }\end{array}$ \\
\hline Animals & $\begin{array}{l}\text { This Little Pig, Two Little Dicky Birds, A Grizzly Bear, An Elephant } \\
\text { Walks, Ants Go Marching, B-I-N-G-O, A Woman and a Dog, A Bee } \\
\text { in My House, Animals Everywhere, Bluebird, Different Pets, Farm } \\
\text { Animals, Ladybug, Ladybug, Naughty Horse, Old MacDonald Had a } \\
\text { Farm, Penguin Song, The Little Frog }\end{array}$ \\
\hline Family & $\begin{array}{l}\text { Mommy, Father's Song, Finger Family, Baby Shark, Father Finger, The } \\
\text { Farmer in the Dell }\end{array}$ \\
\hline $\begin{array}{l}\text { Seasons, weather } \\
\text { and nature }\end{array}$ & $\begin{array}{l}\text { Leaves Are Falling, Rain, Rain, Go Away, Autumn Winds, Deep and } \\
\text { Wide, Four Seasons, Mr Sun, Snowflake, Weather Song, The Rainbow } \\
\text { Song, What a Wonderful World, Twinkle, Twinkle Little Star }\end{array}$ \\
\hline
\end{tabular}




\begin{tabular}{|l|l|}
\hline Food and drinks & $\begin{array}{l}\text { I Like Coffee, I Like Tea, I Like to Eat Apples and Bananas, Cut the } \\
\text { Cake, Can I Have a Banana? Coffee, Coffee, Milk and Sugar, Do You } \\
\text { Want an Apple? Fruit Song, Happy Fruits, Hungry Song }\end{array}$ \\
\hline Colours & $\begin{array}{l}\text { I Can Sing a Rainbow, Brown Bear What Do You See? What Colour Is } \\
\text { Mum's Hat? What Colours Do You Like? }\end{array}$ \\
\hline $\begin{array}{l}\text { Numbers and } \\
\text { the alphabet }\end{array}$ & $\begin{array}{l}\text { Ten Little Indians, Ten Little Fingers, 1,2,3,4,5 Once I Caught a Fish Ali- } \\
\text { ve, Five Currant Buns, Five Little Speckled Frogs, How Many Elephants? } \\
\text { The Big Numbers, There Were Ten in the Bed, This Old Man, ABC }\end{array}$ \\
\hline Festivals & $\begin{array}{l}\text { Hot Cross Buns, Easter Bunny, Five Little Pumpkins, Here Is the } \\
\text { Chimney, I Lava You, Ring Those Turn Around, Skinny Marinky Dinky } \\
\text { Dink, You Are My Valentine }\end{array}$ \\
\hline $\begin{array}{l}\text { Songs and } \\
\text { rhymes around } \\
\text { stories }\end{array}$ & $\begin{array}{l}\text { I Am Not Afraid of the Big Bad Wolf, Little Red Riding Hood, Skeleton } \\
\text { Dance, Three Little Piggies, Snow White, The Very Hungry Caterpillar, } \\
\text { We Are Going on a Bear Hunt, Three Bears }\end{array}$ \\
\hline
\end{tabular}

The researchers find it fascinating that, after greetings, the most common topic is festivals. This predilection is understandable since many preschools organise their pedagogical programme around the seasons and special days. The rhymes and songs feature almost all the holidays, including Christmas, Easter, Halloween, Valentine's Day, Mother's Day, and Father's Day. Although there was at least one song for each festival, most songs and rhymes gathered in the course of this research displayed themes related to Christmas or Halloween and in a range of genres spanning traditional carols to simple chants and tailor-made rhymes.

Out of the list mentioned above, Christmas and Halloween are probably the most popular and relevant holidays in children's lives. While Christmas is one of our best known, standard holidays (combined with gifts) worldwide, Halloween is a bit more controversial regarding its nature and celebration beyond the English-speaking cultures. For example, in Hungarian culture, Halloween's celebration in its Anglo-Saxon form is not a part of school or kindergarten traditions; in general, only English teachers and specialised classes and groups celebrate it. In several cases, non-EFL primary or kindergarten teachers might feel averse to this festival even though Hungarian traditions (The Day of the Dead) and Halloween are entirely distinct. However, the significance of the small 'c' culture (Kramsch, 1998) is indicated by the fact that EFL teachers incorporate a holiday with relevant and engaging content for young children. Thus, besides traditional local festivities, Anglo-Saxon (children's) cultural aspects may appear in the local pedagogy programme of CLIL institutions. (See the list of songs and rhymes related to the two, main holidays in Table 4). 
Table 4

List of songs related to Christmas and Halloween

\begin{tabular}{|l|l|}
\hline \multicolumn{1}{|c|}{ Christmas } & \multicolumn{1}{c|}{ Halloween } \\
\hline We Wish You a Merry Christmas & Trick or Treat \\
\hline All I Want for Christmas Is My Two Front Teeth & Ghosts and Goblins \\
\hline Angels We Have Heard on High & Halloween Night \\
\hline Here Is the Chimney & Halloween Numbers \\
\hline Last Christmas & Knock, Knock, Treat or Trick \\
\hline Rudolph, the Red-Nosed Reindeer & Skeleton Dance Song \\
\hline Santa Claus Is Coming to Town & Five Little Pumpkins \\
\hline Oh, Christmas Tree & \\
\hline The Dancing Christmas Tree & \\
\hline Five Little Snowmen & \\
\hline Ring Those Bells and Turn Around & \\
\hline
\end{tabular}

Hungarian and Catalan teachers exploit and share the same genres of children's literature with the exception that Hungarian teachers used an extra category: chants. The origin of utilising chants in foreign language teaching goes back to jazz chants' first appearance in Hungary. Jazz chants became popular and widespread among English teachers thanks to the author and musician, Carolyn Graham (1979, 1992, 2000), who has given numerous inspirational presentations on jazz chants at ELT conferences in Hungary. It is therefore unsurprising that many chants can be found in the Hungarian teachers' comprehensive list. The chants share the original jazz chants' main characteristic features: rhythm and rhyme (Do You Want an Apple Chant, Babyface Chant, Coffee, Coffee Chant, Abracadabra Chant, I Don't Like This Jumper Chant).

As regards the Hungarian data, the Catalan researchers were surprised by the presence of modern songs from popular culture in early years' development. The list contains the following songs related to greetings, holidays, everyday events or feelings: Dancing in The Street by David Bowie \& Mick Jagger, Englishman in New York by Sting, Hello, Goodbye by The Beatles, Hold My Hand by Michael Jackson, See You Again by Wiz Khalifa ft. Charlie Puth, What a Wonderful World by Louis Armstrong, Last Christmas by Wham. A less-surprising finding is a subcultural item possessing minimal cultural or literary value. Adored by children worldwide, the pop industry's current product, The Baby Shark Song (URL 9), was mentioned by teachers and the data also contained Disney songs (I Lava You URL 10). 


\section{Conclusion}

The goal of the present article was to conclude a joint research project conducted by the University of Vic and ELTE TÓK. This research focused on applying English children's literature within language classrooms for young language learners in Catalan and Hungary. Beyond its practical application, this project also comprised a significant stepping stone in professional collaboration among the four authors.

In conclusion, the follow-up research succeeded in providing further valuable insight into the practice of using children's literature in TEYL in Catalan and Hungarian primary schools and kindergartens. A surprising finding is the minimal overlap between the children's stories used by EFL teachers in Catalonia versus Hungary. This phenomenon may be due to the fact that teachers tend to select stories and picture books according to their own preferences, yet also do so while weighing their learners' language level, needs, and interests. The diversity of the titles observed in both countries suggests that teachers are aware of the exceptional potential that stories can offer and make use of a wide range of books to achieve their teaching aims. Their different choices may reflect the accessibility of certain books, their personalities, and varied teaching experiences. Beyond these factors, some differences may originate from what books teachers have been exposed to during their initial and in-service teacher training or their native-speaking lectors' suggestions.

Comparing the Catalan and Hungarian survey results concerning the application of songs and rhymes in primary and preschool education proved that teachers use both extensively. A somewhat unexpected, yet pleasant finding was that the range of songs and rhymes collected in this research project is relatively wide. It seems that teachers of young learners know many works from children's literature and regularly select texts to supplement the themes in their curricula. This result reflects a highly conscious professional attitude to utilising songs and rhymes.

The research provided invaluable insight into the application of children's literature in TEYL within the two contexts and added meaningful knowledge to the researchers' work as teacher trainers. The four authors all teach Children's Literature courses in their university's BA programmes in preschool and primary education; thus, they can channel the project's conclusions into their teaching. This research cooperation deepened their professional understanding of one another and led them to embark on a joint project that was conducted on a larger scale. This collaboration between international partners benefits their pedagogical work at their home institutions.

Special thanks to the teachers in Hungary and Catalonia who compiled their lists of songs and stories:

Ildikó Kámánné Vajda and her colleagues, Magdolna Kovács, Noémi Kovács, Szabina Gaál, Tímea Fazekas; 
Cristina Vicente, Tània Coll, Remei Solà, Sandra Gutiérrez, Reies Font, Albert Jordà, Cecilia Font, Laura Parés, Glòria Surinyach, Marta Vergés, Anna Écija, Imma Puntí, Maite Ceballos, Meritxell Portet, Vicky Gasch, Mariona Fletas, Núria Serra, Jessica Castillo, Belén Ocaña.

\section{References}

5/2020 (I.31.) A Nemzeti alaptanterv kiadásáról, bevezetéséről és alkalmazásáról szóló 110/2012. (VI. 4.) Korm. rendelet módosításáról (2020.) Magyar közlöny,(17) 290-446.

Bland, J. (2019). Teaching English to Young Learners: More Teacher Education and More Children's Literature! CLELE Journal, 7(2), 79-103. https://clelejournal.org/ wp-content/uploads/2019/11/Teaching-English-to-Young-Learners-more-TEdand-more-Children\%e2\%80\%99s-Literature-CLELE-7.2-1.pdf (2021.01.31.)

Bland, J. (2016). Oral Storytelling in the Primary English Classroom. In Bland, J. (Ed.), Teaching English to Young Learners (pp. 183-198). Bloomsbury.

Canals-Botines, M. (2020). Teaching Narrative Structures to Students majoring in Pre-School and Primary Education. Studi sulla Formazione/Open Journal of Education, 23(1), 175-186.

Canals-Botines, M. \& Medina-Casanovas, N. (2019). Songs and Narrative Structures in Storybooks for Young Learners. In Camps-Casals, N., Canals-Botines, M. \& Medina-Casanovas (Eds.), Storytelling Revisited 2018 Gender, Language, Music, Cinema (pp. 25-36). Universitat Central Catalunya.

Canals-Botines, M. \& Medina-Casanovas, N. (2020). Songs and Narrative Structures in Storybooks for Young Learners. Budapest Schools Collection. In Camps-Casals, N., Canals-Botines, M. \& Medina-Casanovas (Eds.), Storytelling Revisited 2019 Gender, Language, Music, Cinema (pp.51-60). Universitat Central Catalunya.

Coyle, Y. \& Gómez Gracia, R. (2014). Using songs to enhance L2 Vocabulary acquisition in preschool children. ELT Journal, 68(3), 276-285. https://doi. org/10.1093/elt/ccu015

Council of Europe (2020). Companion Volume to the Common European Framework of References for Languages: Learning, Teaching, Assessment. Council of Europe Publishing.

Ellis, G. \& Brewster, J. (2014). Tell it Again! The New Storytelling Handbook for Primary Teachers 2002. The British Council.

ELTE TÓK (2020). Tantervi tájékoztató az alapképzési tanulmányaikat az ELTE Tanitó és Óvóképző Karán 2020 szeptemberében megkezdő hallgatók részére: Tanitó Szak. https://www.tok.elte.hu/dstore/document/1429/NTK_taj_2020_Bp.pdf (2021.02.17).

ELTE TÓK (2020). Tantervi tájékoztató az alapképzési tanulmányaikat az ELTE Tanító- és Óvóképző Karán 2020 szeptemberében megkezdő hallgatók részére: Óvodapedagógus Szak. https://www.tok.elte.hu/dstore/document/1434/NOK_ taj_2020.pdf (2021.02.17.) 
Fonseca-Mora, C. (2000). Foreign language acquisition and melody singing. ELT Journal, 54(2), 146-152. https://doi.org/10.1093/elt/54.2.146

Graham, C. (1979). Jazz Chants for Children. Oxford University Press.

Graham, C. (1992). The Chocolate Cake: Songs and Poems for Children. Delta Systems.

Graham, C. (2000). Jazz Chants Old and New. Oxford University Press.

Kersten, S. (2016). Language Development in Young Learners: The Role of Formulaic Language. In Bland, J. (Ed.), Teaching English to Young Learners (pp. 129-146). Bloomsbury.

Kramsch, C. (1998). Language and Culture. Oxford University Press.

Mourao, S. (2016). The Potential of Picturebooks with Young Learners. In Bland, J. (Ed.), Teaching English to Young Learners (pp. 199-218). Bloomsbury.

Trentinné Benkő, É. (2016). Ten years of CLIL Teacher Training at ELTE TÓK. In Karlovitz, T. J. (Ed.), Studies from Education and Society (pp. 142-152). International Research Institute sro. https://doi.org/10.18427/iri-2016-0093

\section{Webography}

URL 1: The Best 100 Children's Books (Timeout): https://www.timeout.com/ london/kids/the-100-best-childrens-books (2021.02.15.)

URL 2: The 100 Best Children's Books of all Time (Time Magazine): https://time. com/100-best-childrens-books/ (2021.02.15.)

URL 3: New York Public Library: Top 10 Checkouts of All Time: https://www.nypl. org/125/topcheckouts (2021.02.15.)

URL 4: Awards won by The Very Hungry Caterpillar: https://eric-carle.com/abouteric-carle/awards/ (2021.02.15.)

URL 5: Winnie's song: https://www.youtube.com/watch?v=0KvDF4F5GYw (2021.02.15.)

URL 6: Penguin song: https://www.youtube.com/watch?v=He5Xu11HBkM (2021.02.15.)

URL 7: Owl song: https://www.youtube.com/watch?v=7kEjZHKXLDg (2021.02.15.)

URL 8: Clean up song: https://www.youtube.com/watch?v=SFE0mMWbA-Y (2021.02.15.)

URL 9: Baby Sharksong: https://www.youtube.com/watch?v=K2fkCcjzBrQ (2021.02.15.)

URL 10: I Lava You song: https://www.youtube.com/watch?v=uh4dTLJ9q9o (2021.02.15.) 


\section{List of picture books mentioned in the text}

Carle, E. Brown Bear, Brown Bear. (Puffin Books)

Carle, E. The Very Hungry Caterpillar. (Puffin Books)

Donaldson, J. \& Scheffler, A. The Gruffalo. (Macmillan)

Rosen, M. \& Oxenbury, H. We're Going on a Bear Hunt. (Walker Books)

Thomas, V. \& Corky, P. Winnie the Witch. (Oxford University Press)

Thomas, V. \& Corky, P. Winnie and Wilbur Meet Santa. (Oxford University Press)

\section{Appendix A}

\section{Data Collection Tool for Schools and Kindergartens}

Data Collection Tool for Schools and Kindergartens by Canals-Botines E Medina-Casanovas (2019)

\begin{tabular}{|c|c|c|c|c|}
\hline \multicolumn{5}{|l|}{$\begin{array}{l}\text { Name of } \\
\text { school }\end{array}$} \\
\hline \multicolumn{5}{|l|}{ Address } \\
\hline \multicolumn{5}{|l|}{ Country } \\
\hline \multicolumn{5}{|l|}{$\begin{array}{l}\text { Total number } \\
\text { of students }\end{array}$} \\
\hline \multicolumn{5}{|l|}{$\begin{array}{l}\text { Number of stu- } \\
\text { dents learning } \\
\text { English }\end{array}$} \\
\hline School year & Song & Video/Film & Textbook & Other \\
\hline & & & & \\
\hline & & & & \\
\hline
\end{tabular}

Trentinné Benkö Éva: https://orcid.org/0000-0002-0525-7361

Árva Valéria: https://orcid.org/0000-0002-6346-6241

Medina-Casanovas, Núria: https://orcid.org/0000-0002-8002-4453

Canals-Botines, Mireia: https://orcid.org/0000-0003-4481-4447 